\title{
DETERMINANTS OF PUBLIC EXPENDITURES FOR MEDICINAL PRODUCTS IN NON HOSPITAL CONSUMPTION IN SLOVENIA
}

\author{
Romana Kajdiž, Štefan Bojnec
}

\section{Introduction}

With an aging of the population [2], the population's needs for health services have increased in the European Union (EU-27) as well as in Slovenia. Because of this increases the burden on the country's local public health services and care have increased. The policy response is to save or reduce their operating costs. These policy measures include the rational use of medicinal products and public procurement of cheaper medicinal products. They [1] noted that the expenditures on medicinal products have increased within the EU member states, and therefore argue that the market regulation and pricing of drugs and reimbursement of medicinal products is an important tool to control public spending for medicinal products.

The government with legislation and economic policy measures seek to reduce and to have under control public spending for medicinal products. The purpose of the price regulation system of medicinal products is to reduce public expenditures for pharmaceutical products that are charged by the health insurers and are aimed for finding the optimum balance between maintaining the access to essential medicinal products and the rational use of public funds for medicinal products. The price for medicinal products is only one of the essential factors for the public expenditures. [9], [10]

During the past decades, several EU countries, as well as some other countries (e.g. New Zealand, Australia, Canada and South Korea) ([7], [17]), have implemented various forms of price regulation. The aim of the price regulation for medicinal products is to control the costs and the health expenditures for prescription of drugs. Authors [6] and [3] believe that price regulation is one of the most important tools by which economic policy measures can be used to control and limit the costs of medicinal products. The growth of the public expenditures for medicinal products is the one of the influencing factors for the increase in public spending in health care in most developed countries. To limit the growth of expenditures for medicinal products the competent authorities, particularly in EU-27, initiated regulatory measures, which attempt to influence to the market developments, especially on the supply side [12]. EU countries have different national pharmaceutical systems, not only because of different historical, political, legal and economic trends, but also because of the ways in which they finance the health care systems [18]. These countries are facing the same challenges of how to provide the population with affordable access to medicinal products, with limited available public resources [11]. Over the past ten years, average spending per capita on medicinal products in EU countries has risen by almost $50 \%$ in real terms. The evidence for OECD countries suggests considerable variation in medicinal products spending, reflecting differences in volume, structure of consumption and pharmaceutical pricing policies [14].

In this article we aim to establish the association between the regulated wholesale prices of medicinal products and the public expenditures for medicinal products. The public expenditures on medicinal products in the regression model are specified with emphasis on the regulated wholesale prices of medicinal products. 


\section{Health Care System for Medicinal Products in Non Hospital Consumption in Slovenia}

A linear increase in consumption of medicinal products in Slovenia during the recent years has been determined by a continuous increase medicinal products treatment of an aging population, an increased detection of chronic diseases and complex therapeutic guidelines [5]. In Slovenia there has been prescribing the number of new, substantially more expensive medicinal products for a similar or an entirely new medical indication. Like in other developed countries, the Slovenian population is more and more informed about medical patients' treatments. Therefore, this has demanded more public funds for consumption of medicinal products, which have been prescribed by the medical doctors on outpatient prescription (Rp). Those reasons have been leading to a rising the public expenditures for medicinal products in the recent years in Slovenia. At the same time they have caused a debate about the economic efficiency of the public health system. Therefore, the spending of the public funds and the price regulation system for medicinal products, they have increasingly been under a scrutiny of government policy. Legislation, regulatory and economic policy measures have been used in Slovenia at aiming to reduce and control public spending on medicinal products.

Each medicinal product that is present in the Slovenian market must have valid marketing authorization and should have set a price. Medicinal products which are financed from public funds should have regulated wholesale prices in accordance with applicable law. Medicinal products which compete for entry on the list of medicinal products that are wholly or partially financed by public funds covered by the compulsory and supplementary health insurance, they should have first formed the wholesale price in accordance with the applicable rules for the design and pricing of medicinal products. The wholesale price is determined by comparing the basket of reference medicinal product prices or the reference price or international or an external reference price. These comparative countries are Germany, France and Austria, which have replaced Italy in 2007. The system of the mutual interchangeable medicinal products (MZZ) in Slovenia is used to regulate prices of medicinal products namely internal reference prices. This system is applied only to some groups of medicinal products organized in clusters having the same active principle, strength and formulation. The $M Z Z$ list with maximum recognized value (MZZ z NPV) determinates the maximum value that is covered by the compulsory public health insurance. This is in responsibility of the Standing Committee for Medicinal Products. The additional decisions for ranging the medicinal products in the lists have been in the responsibility of the Public Health Care Service of Slovenia. Medicinal products can be classified in the positive list, the intermediate list, by limiting the prescription laid down by the Public Health Care Service of Slovenia, or not classified that are on a negative list [15]. Maximum recognized value (NPV) is the price of the medicinal product, which is covered by the Public Health Care Service of Slovenia in accordance with the classification of medicinal product on the lists: at $75 \%$ for medicinal products at the positive list, at the $25 \%$ for medicinal products at the intermediate list, and at $100 \%$ for specific examples. In 2009 , there have been made some changes. The NPV is the price of the product value for each medicinal product covered by the Public Health Care Service of Slovenia in accordance with the classification of the medicinal products on the lists: at $100 \%$ for the positive list $\mathrm{P} 100$, at $75 \%$ for the positive list P75 and at $10 \%$ for the intermediate list. If the price for medicinal products is higher than the NPV, the patients need to pay the difference between the actual cost of medicinal product and the set NPV. The final price of each medicinal product also increases for the cost of margins, which are charged by the dispensing pharmacy. The costs of pharmacy services is not tied to the price of medicinal products, but is fixed. It is defined in the sectoral agreement for pharmaceutical activity.

The health care and health insurance legislation in Slovenia provides compulsory and voluntary health insurance, which affects the manner of payments of costs for medicinal products. The burden of compulsory health insurance may be classified only for prescribed medicines and foods for special purposes. The compulsory health insurance covers at least $75 \%$ of the value of the positive list and a maximum of $50 \%$ for the intermediate medicinal product from the list. 
The MZZ list entered into force in Slovenia in November 2003. The initial list was compiled by the competent authority for medicinal products [15]. Since 2007, the Public Agency of the Republic of Slovenia for Medicinal Products and Medical Devices has updated this list. The system operates on a comparison of the scheduled medicinal products with the same non-proprietary name or the same substance, which corresponds to a number of brand names of medicinal products with different prices. At least one of the medicinal products with the same non-proprietary name and comparable packaging must be within the NPV. The introduction of the $M Z Z$ has brought some positive economic effects from a more rational prescribing of medicinal products. These has occurred owing from a larger share of a prescription of parallel medicinal products with the lower price, and owing from the lowering of prices of certain medicinal products from manufacturers just before and during the period following the implementation of the MZZ by setting the NPV. The effects were most noticeable in the first years after the introduction of the system [15].

In Slovenia the ratio between the total costs for medicinal products and the costs of medicinal products, which were covered by the Public Health Care Service of Slovenia, has changed over the years. In $2000,79.2 \%$ of all costs for medicinal products were covered by the Public Health Care Service of Slovenia, while $63.8 \%$ in 2010 [15]. The total costs for medicinal products and the share covered by the Public Health Care Service of Slovenia depend largely on the classification of medicinal products on one of the lists and on prices of medicinal products.

The study of developments of regulated wholesale prices of medicinal products in Slovenia in the period from 2003 to 2010 showed that the regulated wholesale prices of medicinal products, which were publicly funded and were prescribed on an outpatient $R p$, have been reduced over the analysed period. The price regulation system of medicinal products in Slovenia has become an important mechanism for the control of public spending on pharmaceuticals. [9], [10]

\section{Data Used in the Study}

In this study we used data on the consumption of medicinal products, which are published on the website of the Public Health Care Service of Slovenia and ranged them into the balanced panel data, which were selected based on the following criteria: medicinal products, data available in all studied periods, and should have regulated wholesale price, which financed by public funds. We included the following variables: public expenditures on medicinal products prescribed in the outpatient $R p$ covered by the compulsory health insurance, the number of the Rp, the number of boxes of medicinal products prescribed on the $R p$, wholesale prices of medicinal products and lists on which the medicinal products were classified (P100, P75, Q25 and Q10). Data on the number of the Rp, the number of boxes of medicinal products prescribed on the $\mathrm{Rp}$ and the value of medicinal products issued on the $\mathrm{Rp}$ and covered by the compulsory health insurance in Slovenia were obtained on the website of the Public Health Care Service of Slovenia. Data on wholesale prices of medicinal products and classification of them on the lists of medicinal products that are wholly or partly funded from public resources and information on the percentage of the value of wholesale prices and the classification were obtained on the basis of data from the Public Health Care Service of Slovenia. The study analyzed 758 medicinal products regulated prices, financed from public funds in the years 2003-2010. These data are reported in the nominal values. To obtain their real values over the analysed years, the nominal values were deflated by the consumer price index (CPI) with the base year. The CPI deflators are obtained from the Statistical Office of the Republic of Slovenia. They are used to obtain the real price values for medicinal products.

\section{Methodology}

We analyze the relationship between the dependent variable and independent explanatory variables by using the multivariate regression analysis in order to estimate the model parameters and the statistical significance of the model.

The starting point of the empirical analysis is the correlation analysis in order to examine the degree of correlation between the pairs of the analysed individual variables. Finally, the regression analysis of the panel data by employing the ordinary least square method is 


\section{Ekonomie}

used to determine the relationship between the public expenditures on medicinal products and the wholesale price of medicinal products. The regression analysis for the public expenditures on outpatient medicinal products prescribed on the Rp, which are covered by the Public Health Care Service of Slovenia as the dependent variable is specified by using the following explanatory variables: the number of $\mathrm{Rp}$, the number of boxes of medicinal products prescribed on the Rp, the wholesale price of medicinal products and four dummy variables for the lists on which the medicinal product is classified (P100, P75, Q25 and Q10). Each dummy variable takes the value 1 if the medicinal product is classified at the appropriate list and 0 otherwise. Nominal values of the variables are deflated by the CPI. The regression model is estimated in natural logarithms, which means that the regression coefficients at the same time represent the coefficients of elasticity.

The null hypothesis assumes that public expenditures for medicinal products, prescriptions covered by the compulsory health insurance are not associated with the wholesale price of medicinal products, the number of boxes of medicinal products prescribed per prescription or the number of prescriptions of recipes and the list at which the medicinal product is classified (H0: $\theta=0)$. The alternative hypothesis assumes that public expenditures on medicinal products, prescriptions covered by the compulsory health insurance are associated with the wholesale price of medicinal products, the number of boxes of medicinal products prescribed per prescription or the number of prescriptions of recipes and the list at which the medicinal product is classified $(\mathrm{H} 1: \theta \neq 0)$.

\section{Empirical Results}

The correlation analysis showed that there is a high positive correlation between the public expenditures on medicinal products and the number of $\mathrm{Rp}$ or the number of boxes prescribed on the $\mathrm{Rp}$, and there is a positive, but relatively low correlation between the public expenditures on medicinal products and the wholesale price of medicinal product on one hand and the classified list of medicinal products on the other (Table 1).

The regression analysis confirmed that the public expenditures for medicinal product are positively associated with the number of the $R p$ and the number of boxes prescribed on the Rp, the wholesale price of medicinal product, and the lists on which medicinal products are classified.

Correlation coefficients and regressions for public expenditures for medicinal products in non hospital consumption in Slovenia

\begin{tabular}{|c|c|c|c|}
\hline $\begin{array}{l}\text { Dependent variable: public } \\
\text { expenditures on medicinal } \\
\text { products }\end{array}$ & Correlation coefficients & Regression (1) & Regression (2) \\
\hline \multicolumn{4}{|l|}{ Explanatory variables: } \\
\hline Wholesale price & $0.223^{\star * *}$ & $0.866^{* * *}$ & $0.893^{* * *}$ \\
\hline Number of $\mathrm{Rp}$ & $0.661^{* * *}$ & $0.932^{* * *}$ & \\
\hline Number of boxes on the Rp & $0.670^{\star \star *}$ & & $0.971^{* \star *}$ \\
\hline Positive list 100 & $0.031^{* *}$ & $1.931^{\star * *}$ & $1.889^{* \star *}$ \\
\hline Positive list 75 & $0.207^{\star *}$ & $1.510^{\star \star \star}$ & $1.667^{\star \star \star}$ \\
\hline Intermediate list 25 & $-0.106^{\star * \star}$ & $0.978^{* * *}$ & $1.051^{* * *}$ \\
\hline $\mathrm{N}$ & 6,064 & 6,064 & 6,064 \\
\hline Adjusted R2 & & 0.896 & 0.937 \\
\hline F-test & & $10,446.3$ & $18,096.9$ \\
\hline
\end{tabular}

Source: own

Note: ${ }^{\star \star \star} p<0.001 ;{ }^{\star \star} p<0.05$. Public expenditures on medicinal products, the wholesale price, the number of the Rp and the number of boxes on the $\mathrm{Rp}$ are expressed in natural logarithms. 


\section{Discussion}

The correlation and regression analysis confirmed a positive association between the wholesale price of medicinal product and the public expenditures for medicinal products. There was also a positive association between the public expenditures for medicinal products and the number of the Rp or the number of boxes required on the $\mathrm{Rp}$. The explanatory variables included in the regression model explained $94 \%$ of the variability of the public expenditures for medicinal product. The set dummy variables for the list classification (P100, P75 and Q25) were positively associated with the public expenditures for medicinal products. Elasticity coefficients indicate that an increase the number of the Rp for $1 \%$ leads to an increase in the public expenditures for medicinal products by $0.932 \%$. The increase in the number of boxes of medicinal products prescribed on the $\mathrm{Rp}$ by $1 \%$ leads to an increase in the public expenditures for medicinal products by $0.971 \%$. The increase in the wholesale price of medicinal products prescribed on the $\mathrm{Rp}$ by $1 \%$ leads to an increase in the public expenditures for medicinal products by $0.866 \%$ or $0.893 \%$. The previous analysis ([9] and [10]) confirmed that the wholesale prices of medicinal products have declined during the price regulation system. The empirical results confirmed that the public expenditures for medicinal products issued on the $\mathrm{Rp}$, which are covered by the compulsory health insurance, are related to the number of the $R p$ or the number of boxes prescribed on the Rp and the wholesale price of medicinal products and the lists to which the medicinal products are classified. The public expenditures for medicinal products are affected by the number of prescribed medicinal products, which are issued by the Rp and the number of boxes of medicinal product, which are prescribed on the $\mathrm{Rp}$, and the developments of the regulated wholesale prices for medicinal products.

The empirical analysis confirmed the alternative $\mathrm{H} 1$ hypothesis, which says that there is a positive association of the public expenditures for medicinal products with the number of boxes of medicinal product, which prescribed on the $R p$, the number of the $R p$ prescriptions, the wholesale price of medicinal products and the lists to which the medicinal product is classified.
The regulated wholesale price affects the public expenditures for medicinal products, but on the public expenditures for medicinal products has a significant positive impact also the number of the Rp or the number of boxes of medicinal products, which are prescribed on the Rp. Effective, safe and quality treatment of patients with medicinal products is not proportional to the number of medicinal products that each patient receives. The aim of pharmacological treatment is the best possible quality of life of patients. Safe and effective quality treatment and consequently costeffective medical treatment depends largely on a correct assessment of a medical doctor regarding medical conditions for the individual patient that should be treated with medicinal products. Crucial is the responsible prescribing of medicinal products on the RP. The consumption of medicinal products in Slovenia measured in the defined daily doses in the last ten years increased, while the number of persons, who received this medicine, has not significantly increased. This suggests that the same people received more medicinal products and the consumption of medicinal products per beneficiary has increased over time. There is an increased risk of adverse interaction and negative reaction on medicinal products use, and more difficult is to manage costs for medicinal products in a sustainable way vis-àvis budgetary limitations. The polipharmacy the co-administration of five or more medicinal products simultaneously - is in the exceptional growth, which to some extent also leads to increasing health damages and additional economic costs. The responsible prescribing of medicinal products, which requires consideration of medical and economic aspects of prescription of medicinal products, is of a substantial relevance. The prescribing of medicinal products should be derived from the medicinal findings of which medicinal products are really necessary to treat patients and at the same time to reduce irrational prescribing. For more responsible and proper use of medicinal products it is necessary to inform and educate patients in order to consider rational use and to prevent irrational behaviour which requires prescription of medicinal products without adequate medical treatment. 


\section{Conclusions}

The regression analysis has confirmed that the public expenditures for medicinal products were a positively associated with the regulated wholesale prices of medicinal products. This implies the decrease in the wholesale prices of medicinal products has caused the decrease in the public spending for medicinal products. The results of the regression analysis confirmed the relationship between the lists on which the medicinal product is classified and the public expenditures for medicinal products. The public expenditures for medicinal products were also significantly determined by the number of prescribed $\mathrm{Rp}$ and the number of boxes of medicinal products on the Rp prescription. In the regression model included variables explained a high percentage of the public expenditures for medicinal products. To a lesser extent the regression results are affected by some other factors, which were not specified in regression model such as valueadded tax and pharmacy services. The regulation of the wholesale prices for medicinal products and encouraging more conservative prescribing could play an important role in management of public spending for medicinal products [16]. The consumption of medicinal products in Slovenia has increased over time. New medicinal products and new areas of medical treatments, higher prescribed doses of medicinal products, aging of the population and the related polipharmacy, have rapidly increased costs for use of medicinal products. They go beyond the sustainable financial ability of the Public Health Care Service of Slovenia. This situation is similar to the public health systems in most of developed countries. Therefore, to reduce costs and public health expenditures is a challenging issue for both health and overall economic and budgetary policy.

They [4] noted that in the early 1990s, most of governments in Europe decided to implement a mixture of different health policies and policies towards consumption of medicinal products, which are financed from the public funds. These policies focus on the price regulation for medicinal products or on the prescribed amount of medication or a combination of both. The practical experiences confirmed the crucial importance of mix of fair pricing policy and regulation quantities for medicinal products. As the regression analysis confirmed the public financing expenses were significantly positively associated with the number of $R p$ and the number of boxes prescribed on the Rp. This reflects the importance of the pricing policy and regulation quantities for medicinal products, which were intended for consumption financed by the public expenditures.

Rational prescribing of medicinal products and their rational use in accordance with the medical instructions are the factors that could affect the costs and public expenditures for medicinal products without reductions of the rights of insured for medical products. Rational prescribing of medicinal products could not be considered as a measure for limiting the access to medicinal products, but rather the appropriate way of utilization of limited available public resources for medicinal products. The monitoring of the expenditures for medicinal products in Slovenia has included regulated pricing, scheduling of medicinal products on the lists (the system of the MZZ with NPV and medicinal products with limited prescription), education and information for medical doctors, pharmacists and users on the appropriate and rational management in the use of medicinal products. The aim in Slovenia has been to reduce the public expenditures for medicinal products. This has been included in the regime of medical treatments, which allows the inclusion of new and more effective medicinal products in the health system.

The article does not address the issues of consumption of medicinal products, which were used in hospitals ([8] and [13]). The reason for this lies in a fact that the observed period was not accompanied by data on the use of medicinal products in the hospitals. The prices of medicinal products in the hospitals were determined by the similar procedure as the prices of medicinal products with the $\mathrm{Rp}$ prescription. The consumption of medicinal products in hospitals is an issue future research.

\section{References}

[1] ARTS, D., HABL, C., ROSIAN, I., VOGLER, S. Pharmaceutical pricing and reimbursement information (PPPI): a European Union project. Italian Journal of Public Health. 2006, Vol. 3, Iss. 1, pp. 213-234. ISSN 1723-7815. 
[2] ČEPAR, Ž. Visokošolsko izobraževanje v Sloveniji: analiza povpraševanja. Koper: Založba Univerze na Primorskem, 2010. ISBN 978-9616832-01-4.

[3] DICKSON, M., REDWOOD, H. Pharmaceutical reference prices: How do they work in practice? Pharmacoeconomics. 1998, Vol. 14, Iss. 5, pp. 471-479. ISSN 1170-7690.

[4] ESPIN, J., ROVIRA, J. External Price Referencing. WHO/HAI project on medicines prices and availability. Policy paper, 2010.

[5] FÜRST, J., SAMALUK, V. Predpisovanje zdravil v letu 2006. Zdravstveni Vestnik. 2007, Vol. 76, pp. 487-489. ISSN 0350-0063.

[6] GIULIANI, G., SELKE, G., GARATTINI, L. The German experience in reference pricing. Health Policy. 1998, Vol. 44, Iss. 1, pp. 73-85. ISSN 0168-8510.

[7] LEE, I-H., BLOOR, K., HEWITT, C., MAYNARD, A. The effects of new pricing and copayment schemes for pharmaceuticals in South Korea. Health Policy. 2012, Vol. 104, Iss. 1, pp. 40-49. ISSN 0168-8510.

[8] JÁNOŠÍKOVÁ, L. Reduction of a hospital network as a multiple criteria optimisation problem. E+M Ekonomie a Management. 2009, Vol. 12, Iss. 3, pp. 50-57. ISSN 1212-3609.

[9] KAJDIŽ, R., BOJNEC, Š. Ali regulacija in kritje cen zdravil vplivata na javne izdatke za zdravila? Zdravniški vestnik. 2012, Vol. 81, No. 9, pp. 618625. ISSN 1581-0224.

[10] KAJDIŽ, R., BOJNEC, Š. Učinki sistema referenčnih cen na oblikovanje cen zdravil. Management. 2010, Vol. 5, Iss. 1, pp. 53-67. ISSN 1854-4231.

[11] LEOPOLD, C., VOGLER, S., MANTELTEEUWISSE, A.K., DE JONCHEERE, K., LEUFKENS, H.G.M., LAING, R. Differences in external price referencing in Europe A descriptive overview. Health Policy. 2012, Vol. 104, Iss. 1, pp. 50-60. ISSN 0168-8510.

[12] MORENO-TORRES, I., PUIG-JUNOY, J., RAYA, J.M. The impact of repeated cost containment policies on pharmaceutical expenditure: experience in Spain. European Journal of Health Economics. 2010, Vol. 12, Iss. 6, pp. 563-573. ISSN 1618-7598.

[13] NEMEC, J., MERIČKOVÁ, B., ŠTRANGFELDOVÁ, J. The ownership form of hospitals from the viewpoints of economic theory and Slovak practice. E+M Ekonomie a Management. 2010, Vol. 13, Iss. 2, pp. 19-31. ISSN 1212-3609.

[14] OECD. Health at a Glance: Europe 2010, OECD publishing. Paris: Organisation for Economic Cooperation and Development, 2010. 130 p. Available also from: http://dx.doi.org/10.1787/ health_glance-2010-en. ISBN 978-92-64-09031-6. [15] PEČAR-ČAD, S., HRIBOVŠEK, T. Ambulantno predpisovanje zdravil $v$ Sloveniji po ATC klasifikaciji v letu 2010. Ljubljana: Inštitut za varovanje zdravja Republike Slovenije, 2011.

[16] SCIFF, G.D., GALANTER, W.L. Promoting more conservative prescribing. JAMA. 2009, Vol. 301, Iss. 89, pp. 865-867. ISSN 1538-3598.

[17] PARK, S.E., LIM, S.H., CHOI, H.W., LEE, S.M., KIM, D.W., YIM, E.Y., KIM, K.H., YI, S.Y. Evaluation on the first 2 years of the positive list system in South Korea. Health Policy. 2012, Vol. 104, Iss. 1, pp. 32-39. ISSN 0168-8510.

[18] VOGLER, S., et al. Pharmaceutical Pricing and Reimbursement Information (PPRI): final report. Luxembourg: DG Health and Consumer Protection of the European Commission, 2007. Available also from: http://ppri.goeg.at.

Romana Kajdiž, MSc.

Public Agency of the Republic of Slovenia for Medicinal Products and Medical Devices romana.kajdiz@jazmp.si

Prof. Dr. Štefan Bojnec, PhD. University of Primorska Faculty of Management stefan.bojnec@fm-kp.si stefan.bojnec@siol.net 


\section{Abstract}

\section{DETERMINANTS OF PUBLIC EXPENDITURES FOR MEDICINAL PRODUCTS IN NON HOSPITAL CONSUMPTION IN SLOVENIA \\ Romana Kajdiž, Štefan Bojnec}

The Slovenian government aims to regulate prices for medicinal products to manage and reduce public expenditures for medicinal products. This paper aims to investigate the association between the regulated wholesale prices of medicinal products and the public expenditures for medicinal products, and to estimate regression model for public expenditures for medicinal products in the non hospital consumption. In the empirical research are included 758 regulated prices for medicinal products prescribed by the outpatients' department on a prescription (Rp) during the years 2003-2010, which are financed from public expenditures. The correlation and regression analyses are used in order to establish the association between the regulated wholesale prices for medicinal products and the public expenditures for medicinal products. The correlation analysis confirmed a strong positive correlation of the public expenditures for medicinal products with the number of $R p$ or the number of boxes on the Rp prescription, a weak correlation with the wholesale prices for medicinal products and with the classification lists of medicinal products. The multiple regression analysis confirmed a positive significant impact of the wholesale price of medicinal products and the number of $R p$ or the number of boxes on the Rp prescription, on the public expenditures for medicinal products. The research has confirmed the association of the public expenditures for medicinal products with the regulated wholesale prices for medicinal products. It has underlined the importance of the rational prescription and use of medicinal products. The explanatory variables included in the regression model for the public expenditures for medicinal products explained up to $94 \%$ of variability in the public expenditures for medicinal products.

Key Words: Price regulation, medicinal products, prescription management, public expenditures, Slovenia.

JEL Classification: H51.

DOI: 10.15240/tul/001/2014-3-003 